\section{Cadmium, lead and mercury in the blood of workers from recycling sorting facilities in São Paulo, Brazil}

\author{
Níveis sanguíneos de cádmio, chumbo e mercúrio \\ em trabalhadores de centros de reciclagem em \\ São Paulo, Brasil
}

\author{
Cadmio, plomo y mercurio en sangre de \\ trabajadores de plantas de reciclaje \\ en São Paulo, Brasil
}

\author{
Mariana Maleronka Ferron 1,2 \\ Rúbia Kuno 3 \\ Anali Espindola Machado de Campos 3 \\ Francisco José Viana de Castro 3 \\ Nelson Gouveia 1
}

\begin{abstract}
Approximately 600,000 people work as recycling material collectors in Brazil and few studies evaluate the health risks involved in this occupation. The objective was to evaluate the blood levels of cadmium $(\mathrm{Cd})$, lead $(\mathrm{Pb})$ and mercury $(\mathrm{Hg})$ among workers from recycling sorting facilities (RSF) in the metropolitan region of São Paulo, Brazil, compare the results with a non-occupationally exposed population, and identify factors associated with higher blood metal levels. Four RSF were selected and 226 collectors were examined for their blood metal levels and associated factors. The mean con-

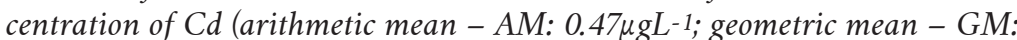
$\left.0.34 \mu g L^{-1}\right)$ was almost four times higher than those found in a reference study. The generalized linear model (GLM) indicated that the "RSF where the collectors work", "work in another occupation", and "smoking" were statistically significant predictors of blood $\mathrm{Cd}$ levels. The Pb mean concentration (AM: 39.13 $\mu \mathrm{gL}-1$; GM: $34.11 \mu \mathrm{gL}-1)$ was also higher than the observed in the reference study (about 1.4 times) and its associated factors in the GLM were "the RSF where the collectors work", "sex", "smoking", "age" and "meat consumption". The Hg mean concentration (AM: $1.46 \mu g L^{-1}$; GM: $\left.0.94 \mu g L^{-1}\right)$ was not significantly higher than the reference population and its associated factors were "previous work in other RSF", "fish consumption" and "years of work in the current RSF". This study indicates that recycling material collectors have higher blood $\mathrm{Cd}$ and Pb levels compared to the general population.
\end{abstract}

Occupational Exposure; Lead; Cadmium; Mercury

\author{
Correspondence \\ M. M. Ferron \\ Rua Lisboa 433, apto. 51, São Paulo, SP 05413-000, Brasil. \\ marimaleronka@yahoo.com.br \\ 1 Faculdade de Medicina, Universidade de São Paulo, São Paulo, \\ Brasil. \\ 2 Faculdade Israelita de Ciências da Saúde Albert Einstein, São \\ Paulo, Brasil. \\ 3 Companhia Ambiental do Estado de São Paulo, São Paulo, \\ Brasil.
}




\section{Introduction}

Approximately 600,000 people work as recycling material collectors in Brazil, although it is difficult to determine the precise number of individuals that are involved in this activity 1 . The work performed by recycling material collectors is carried out in several Latin America countries, and comprises the steps of collection and separation of materials (aluminum, plastic, paper, glass, among others) for posterior delivery to recycling industries 2. Some individuals work collecting discarded material left on the streets and separating them at home. Lately in Brazil some collectors started to work in organizations called recycling material cooperatives located at recycling sorting facilities (RSF). These cooperatives are considered waste management agents with access to financial support and are contracted by municipalities or municipal companies to provide selective collection and segregation services 2 .

According to Bosi 3 , the large number of recycling material collectors is one of the main reasons for the expansion of the recycling market in Brazil. In 2017, 87\% of aluminum and 52\% of paper consumed in the country were recycled 4 . These recycling rates are similar to those reported for European countries (Eurostat. Packing waste statistics. https:/ec.europa.eu/eurostat/statistics-explained/ index.php/Packaging_waste_statistics, accessed on Jan/2019).

In attempting to improve social inclusion and regular income to a large amount of people, in 2010, the Brazilian policy for solid waste management was published with a special emphasis on the work of recycling materials collectors and the RSF 5 . The workers in these facilities are paid according to the amount of material segregated on a day and are registered in the Brazilian social security system 6 .

Despite the inclusion of this activity as a public policy, the environmental importance of the work done by these people and the large number of individuals working as recycling materials collectors, there are only a few studies examining the health implications and risks involved in this occupation.

The materials sent to the RSF are mainly constituted by plastic, glass, paper, and aluminum or other metal cans. On these sites, a reasonable amount of discharged electro electronic equipment (e-waste) can also be found 6 . The recycling process developed at the RSF includes mostly collection, segregation by material type, compacting and sometimes separating major components of e-waste. It is worth noting that burning or dismantling electronic waste is not usual on these facilities 6 .

The potential risks related to the work of recycling material collectors in Brazil include exposure to physical, biological and chemical factors. Ergonomic problems and high risk of mechanical accidents are also associated with this population 6,7.

Regarding the implications of chemical contamination, especially by heavy metals, a study conducted in Porto Alegre, Rio Grande do Sul State, Brazil, found that the activities regularly developed by collectors were associated with lead $(\mathrm{Pb})$ contamination in their children ${ }^{8}$. In a study carried out in two RSF in São Paulo, Brazil 6, the potential risk of exposure to toxic metals was considered high due to the presence of batteries, fluorescent lamps and e-waste mixed with other materials that may contain cadmium $(\mathrm{Cd}), \mathrm{Pb}$ and mercury $(\mathrm{Hg})$ 9. The manipulation of regular waste can also be a potential source of metal exposure, since paper and plastics may contain $\mathrm{Cd}$ and $\mathrm{Pb} 10$.

A study in Sweden showed that workers of a formal recycling plant had significantly higher concentrations of chromium (Cr), cobalt (Co), indium (In), $\mathrm{Pb}$ and $\mathrm{Hg}$ in blood, urine, and/or plasma compared to office workers 11. In Ghana, workers performing informal-level electronic waste (e-waste)-processing activities that included e-waste burning showed high blood $\mathrm{Pb}$ levels compared to individuals without direct exposure to e-waste recycling activities 12 .

It is well documented that $\mathrm{Pb}$ is associated with adverse effects on neurological, renal, cardiovascular, hematological, immunological and reproductive systems. For the general population, exposure to $\mathrm{Pb}$ occurs primarily via oral route, with some contribution of the inhalation route, whereas inhalation exposure may have a more severe role in occupational settings depending on particle size 13 .

High Cd levels in humans are related to adverse effects on neurological, renal, digestive, hematological, and reproductive systems, and this metal is classified as a human carcinogen ${ }^{14}$. Exposure to $\mathrm{Cd}$ can occur through inhalation or via oral ingestion 14 .

The health effects of $\mathrm{Hg}$ depend on the form of the metal (organic or inorganic), the intake route, and exposure duration. The primary source of exposure to organic $\mathrm{Hg}$ comes from fish and marine mammal consumption that may contain methylmercury in their tissues 15 . 
The release of elemental $\mathrm{Hg}$ from the dental amalgam used in fillings is another important source of $\mathrm{Hg}$ exposure. The $\mathrm{Hg}$ content from electrical and electronic equipment can also be related to the inhalation of metallic $\mathrm{Hg} 15$.

Inhalation of metallic $\mathrm{Hg}$ vapor has been associated with systemic toxicity in both humans and animals. The major target organs of metallic Hg-induced toxicity are the kidneys and the central nervous system. At high exposure levels, respiratory, cardiovascular, and gastrointestinal effects also occur 15 .

Considering the potential risk of metal exposure, this study evaluated the blood levels of $\mathrm{Cd}, \mathrm{Hg}$ and $\mathrm{Pb}$ among collectors from RSF in the Metropolitan Region of São Paulo, to compare them to the levels of a non-occupational exposed population and to examine associated factors. These metals were chosen because of their presence in the materials sent to the RSF, the existence of reference values for occupational and non-occupational exposed population, and the health risks they posed.

\section{Material and methods}

A cross-sectional study was carried out to evaluate exposure to heavy metals among recycling material collectors working in RSF in the Metropolitan Region of São Paulo.

The sample size was calculated based on the results of a pilot study that assessed the blood $\mathrm{Pb}$ levels from non-occupational exposed individuals in the municipality of São Paulo 16. Considering a precision of $6 \%$ to determine the average levels of $\mathrm{Pb}$ in the population of collectors with a confidence level of $95 \%$, the required sample size was 271 individuals.

We opted for using a non-occupational exposed population for sample size calculation for two main reasons. First, there were no precise estimatives of the total number of recycling material collectors to base our calculations. Second, although there are some potential sources of metal contamination in the work developed at the RSF, the characteristics of the process applied on the RSF do not indicate exposure levels similar to those present in high risks occupations, i.e. we expected that the population of collectors would not present levels of contamination well above the general population.

To assess metal exposure, we used mean blood metal content. Blood $\mathrm{Pb}$ concentration was used because it is a known biomarker for $\mathrm{Pb}$ exposure. Blood levels of $\mathrm{Cd}$ and $\mathrm{Hg}$ were chosen as they can reflect a more recent exposure since urinary levels of these metals, although more suitable for occupational assessment, reflect longer exposure periods 17 . The collectors, despite being formal workers, have a higher turnover and the length of time working at an RSF is very variable. Thus, it was likely that their exposure history would be too short to be evaluated by other methods.

The first step to our study was to attend several meetings with the leaders of the Brazilian National Movement of Recycling Collectors (MNCR), who indicated some facilities for preliminary visits. After these visits, we selected four RSF, here named A, B, C and D, with characteristics that were common to the majority of recycling facilities and offered better reception to our research team.

The four RSF selected had in total 308 workers. Previously, a meeting was held with all the workers to explain the objectives of the study. Afterwards, interviews were conducted with the person in charge, usually the president or general secretary, to obtain information about the general characteristics of the work organization process, type of equipment used, the presence of potentially contaminating materials, and possible sources of local environmental contamination. A second visit was held to collect individual data information and biological samples. All collectors present on this second day were invited to participate in the study.

Blood was collected using venous phlebotomy and stored in sodium heparin anticoagulant vacutainers that were screened for background $\mathrm{Cd}, \mathrm{Pb}$ and $\mathrm{Hg}$ contamination. Two vacutainer tubes were collected with 4-5mL of blood and sent to the São Paulo State Environmental Agency (CETESB) for analyses.

Duplicate $\mathrm{Cd}, \mathrm{Pb}$ and $\mathrm{Hg}$ analyses were performed on each sample, and the arithmetic mean was recorded for each participant. Blood $\mathrm{Cd}$ and $\mathrm{Pb}$ concentrations were assayed using graphite-furnace atomic absorption spectrometry in a Perkin Elmer A Analyst 600 (Perkin Elmer, Billerica, USA) with AS 72 according to Kummrow et al. 18 at CETESB's laboratory. The limits of quantification (LOQ) for $\mathrm{Cd}$ and $\mathrm{Pb}$ were $0.10 \mu \mathrm{gL}^{-1}$ and $1.6 \mu \mathrm{gL}^{-1}$ respectively. The accuracy and precision of the analyti- 
cal technique to determine these elements in blood were verified using the reference material SeronormTM Trace Elements Whole Blood L-3, which has certified values for the determined analyses. The elements with relative error and standard deviation below 25\% in comparison with the certified values of the reference material were accepted.

Blood Hg was determined by Direct Mercury Analyser (DMA-80 TRICELL, Milestone, Italy) as describe in US. EPA Method 747319 that employs a sequence of thermal decomposition, gold amalgamation and atomic absorption spectrometry. The LOQ for $\mathrm{Hg}$ was $0.10 \mu \mathrm{gL}^{-1}$. For total $\mathrm{Hg}$ determination, two quality control procedures were adopted: daily checking and certified reference material (CRM) checking. The reference material used was Lyphocheck Whole Blood Metals Control Level 1 (BIO-RAD). An independent Hg solution for each absorption cell was prepared and analyzed once the instrument was turned on. The acceptance criterion for its recovery is within $100 \pm 10 \%$ of the presumed concentration. A CRM of blood matrix was analyzed with the same operation conditions used for real samples. The acceptance criterion is within $100 \pm 25 \%$ of the certified concentration.

Basic demographic data and information on lifestyle, including educational level, food and alcohol consumption, smoking habits, source of drinking water, possible external environmental exposure, former disease history, characteristics related to the type of work developed in the RSF, former work experiences and potential sources of metal contamination such as amalgam fillings, hair treatment, etc., were collected by personal interview using a structured questionnaire. Risk for developing chronic obstructive pulmonary disease (COPD) was assessed by a validated questionnaire 20.

The Ethics Research Committee of the University of São Paulo Medical School approved the research protocol. Participation in the study was voluntary, and all subjects signed a Free Informed Consent Form. A reference service of occupational health was offered for those participants who had blood metal levels above the recommended occupational limits.

Brazilian occupational limits for blood metal exposure were not defined for $\mathrm{Cd}$ and $\mathrm{Hg}$ and were considered too high for $\mathrm{Pb}$ compared to other international references 21 . Therefore, to define the individuals that needed referral for further investigation, the limits considered for Cd were $5.0 \mu \mathrm{gL}-1$ and for $\mathrm{Pb} 200.0 \mu \mathrm{gL}^{-1} 22$. For $\mathrm{Hg}$, the limit of $5.0 \mu \mathrm{gL}^{-1}$ was defined considering Human Biomonitoring I (HBM I) 23, a value corresponding to the concentration of a substance in human biological material below wherein no adverse health effects are expected.

Descriptive analysis was performed for the characteristics of the study group and the blood metal concentrations. Concentrations below the LOQ were set to 1/2 LOQ for computational purposes.

The mean blood metal concentration of $\mathrm{Cd}, \mathrm{Pb}$ and $\mathrm{Hg}$ found in each $\mathrm{RSF}$ and in the total population of collectors were compared using a t-test to those found in a study that determined the mean concentrations and reference values for $\mathrm{Cd}, \mathrm{Pb}$ and $\mathrm{Hg}$ from non-occupationally exposed individuals carried out in São Paulo 24.

The comparisons stand to reason since we hypothesized that the work being done at the RSF is not expected to pose the collectors under higher exposure levels of contamination than the general population. For the purpose of comparison with the reference study, only non-smoker individuals were included in the analyses of mean Cd levels $(n=140)$.

A univariate analysis was performed to evaluate associated factors with metal concentrations using $\chi^{2}$ tests, Fisher exact test, likelihood ratio test and Mann-Whitney or Kruskal-Wallis tests. The most important covariables $(\mathrm{p} \leq 0.05)$ in the univariate analyses were included in a Generalized Linear Model. The final models retained variables that were predictive of blood metal levels at a significance level of $\alpha=0.05$.

For the evaluation of the associated factors related with Cd concentration, both smokers and non-smokers individuals were included. All statistical analyses were performed on SPSS 20.0 (https:// www.ibm.com/). 


\section{Results}

During the visits to the RSF a total of 226 individuals were invited and agreed to take part on the study, rendering no refusals (35 in RSF A, 63 in B, 58 in C and 70 in D). This amount represents $73 \%$ of the total workers, with participation rates ranging from $57 \%$ in RSF B to $88 \%$ in RSF D.

The group of collectors was formed mostly of black and brown women, with less than 8 years of schooling and with an average age of 42.5 years. The mean length of time working at the RSF was 46 months and $61.1 \%$ of the collectors mentioned having previously worked on other occupation. Former labor experiences were not precisely reported, probably due to the vulnerability and high turnover on occupational places of this group. The general characteristics of the study population, according to the RSF are shown in Table 1.

$\mathrm{The} \mathrm{Cd}, \mathrm{Pb}$ and $\mathrm{Hg}$ blood concentration of the study group and the reference values for nonexposed population of São Paulo 24 are shown in Table 2.

The means concentration of $\mathrm{Cd}$ found among the collectors (arithmetic mean - AM: $0.47 \mu \mathrm{gL}^{-1}$; geometric mean - GM: $0.34 \mu \mathrm{gL}^{-1}$ ) were almost four times higher than those observed in the reference population. All RSF presented significantly higher mean values, ranging from 2.4 to 5 times the value of the reference population.

The means concentration of $\mathrm{Pb}$ in the collectors were: AM: $39.13 \mu \mathrm{gL}^{-1}$ and GM: $34.11 \mu \mathrm{gL}^{-1}$. Although again all four RSF studied exhibited mean values higher than the reference population, the magnitude of the differences were smaller than for $\mathrm{Cd}$, ranging from 1.2 to 2 times higher.

Regarding Hg, the means concentration (AM: $1.46 \mu \mathrm{gL}^{-1}$; GM: $0.94 \mu \mathrm{gL}^{-1}$ ) were not significantly higher than those found on the reference population and only RSF B presented significantly higher values.

Table 1

General characteristics of the study group, according recycling sorting facilities (RSF). São Paulo, Brazil, 2014.

\begin{tabular}{|c|c|c|c|c|c|}
\hline & \multicolumn{4}{|c|}{ RSF } & \multirow[t]{2}{*}{ Total } \\
\hline & A & B & C & D & \\
\hline \multicolumn{6}{|l|}{ Number of participants } \\
\hline Participants [n (\%)] & $35(70.0)$ & $63(57.0)$ & $58(85.0)$ & $70(88.0)$ & $226(73.0)$ \\
\hline Estimated number of workers & 50 & 110 & 68 & 80 & 308 \\
\hline Mean age (years) & 50 & 43 & 42 & 39 & 43 \\
\hline \multicolumn{6}{|l|}{$\operatorname{Sex}[n(\%)]$} \\
\hline Female & $27(77.1)$ & $31(49.2)$ & $36(62.1)$ & $48(68.6)$ & $142(62.8)$ \\
\hline Male & $8(22.9)$ & $32(50.8)$ & $22(37.9)$ & $22(31.4)$ & $84(37.2)$ \\
\hline Length of time working in the current RSF (months) & 70 & 48 & 49 & 29 & 46 \\
\hline \multicolumn{6}{|l|}{ Work on another RSF [n (\%)] } \\
\hline Yes & $11(31.4)$ & $33(52.4)$ & $18(31.0)$ & $15(21.4)$ & $77(34.1)$ \\
\hline No & $24(68.6)$ & $30(47.6)$ & $40(69.0)$ & $55(78.6)$ & $149(65.9)$ \\
\hline \multicolumn{6}{|l|}{ Work on another occupation [n (\%)] } \\
\hline Yes & $35(100.0)$ & $10(15.9)$ & $42(72.4)$ & $51(72.9)$ & $138(61.1)$ \\
\hline No & $0(0.0)$ & $53(84.1)$ & $16(27.6)$ & $19(27.1)$ & $88(38.9)$ \\
\hline \multicolumn{6}{|l|}{ Smoking habit [n (\%)] } \\
\hline Never & $10(28.6)$ & $20(31.7)$ & $31(53.4)$ & $33(47.1)$ & $94(41.6)$ \\
\hline Former smoker & $11(31.4)$ & $16(25.4)$ & $6(10.3)$ & $13(18.6)$ & $46(20.4)$ \\
\hline Smoker & $14(40.0)$ & $27(42.9)$ & $21(36.2)$ & $24(34.3)$ & $86(38.1)$ \\
\hline \multicolumn{6}{|l|}{ Prior diagnosis of disease [n (\%)] } \\
\hline Yes & $20(57.1)$ & $34(54.0)$ & $20(34.5)$ & $23(32.9)$ & $97(42.9)$ \\
\hline No & $15(42.9)$ & $29(46.0)$ & $38(65.5)$ & $47(67.1)$ & $129(57.1)$ \\
\hline
\end{tabular}


Table 2

Mean metal concentration ( $\mu \mathrm{g} / \mathrm{L})$ of the study group compared to the reference study. São Paulo, Brazil, 2014.

\begin{tabular}{|c|c|c|c|c|c|c|c|c|c|}
\hline Metal/RSF & AM & SD & GM & Median & Minimum & Maximum & $\mathrm{N}<\mathrm{LOQ}$ & $\mathbf{n}$ & $p$-value \\
\hline \multicolumn{10}{|l|}{$\mathrm{Cd}$ * } \\
\hline A & 0.52 & 0.42 & 0.35 & 0.41 & 0.05 & 1.83 & 4 & 21 & $<0.001$ \\
\hline B & 0.5 & 0.23 & 0.47 & 0.46 & 0.33 & 1.74 & 2 & 36 & $<0.001$ \\
\hline C & 0.63 & 0.29 & 0.54 & 0.68 & 0.05 & 1.54 & 0 & 37 & $<0.001$ \\
\hline $\mathrm{D}$ & 0.29 & 0.22 & 0.18 & 0.35 & 0.05 & 0.8 & 19 & 46 & $<0.001$ \\
\hline Total & 0.47 & 0.31 & 0.34 & 0.44 & 0.05 & 1.83 & 25 & 140 & $<0.001$ \\
\hline Ref. & 0.12 & 0.15 & 0.08 & 0.05 & 0.05 & 1.7 & 348 & 539 & Ref. \\
\hline \multicolumn{10}{|l|}{$\mathrm{Pb}$} \\
\hline A & 32.85 & 13.39 & 30.8 & 32.7 & 8.4 & 73.6 & 0 & 35 & 0.042 \\
\hline B & 54.58 & 29.99 & 48.8 & 47.1 & 20 & 207 & 0 & 63 & $<0.001$ \\
\hline C & 31.95 & 18.75 & 28.13 & 28.9 & 9.3 & 122 & 0 & 58 & 0.026 \\
\hline D & 34.3 & 18.38 & 30.19 & 28.75 & 14.9 & 121 & 0 & 70 & 0.001 \\
\hline Total & 39.13 & 23.69 & 34.11 & 33.25 & 8.4 & 207 & 0 & 226 & $<0.001$ \\
\hline Ref. & 27.12 & 15.48 & 23.7 & 23.6 & 1.3 & 131 & 0 & 539 & Ref. \\
\hline \multicolumn{10}{|l|}{$\mathrm{Hg}$} \\
\hline A & 1.36 & 1.4 & 0.86 & 0.83 & 0.05 & 6.35 & 3 & 35 & 0.952 \\
\hline B & 1.75 & 2.27 & 1.04 & 0.8 & 0.21 & 10.35 & 2 & 63 & 0.029 \\
\hline C & 1.37 & 0.88 & 1.08 & 1.24 & 0.05 & 4.8 & 0 & 58 & 0.916 \\
\hline D & 1.32 & 1.52 & 0.77 & 0.76 & 0.16 & 8.72 & 0 & 70 & 0.796 \\
\hline Total & 1.46 & 1.63 & 0.94 & 0.9 & 0.05 & 10.35 & 5 & 226 & 0.242 \\
\hline Ref. & 1.35 & 1.55 & 0.98 & 0.9 & 0.1 & 21.1 & 9 & 552 & Ref. \\
\hline
\end{tabular}

AM: arithmetic mean; Cd: cadmium; GM: geometric mean; Hg: mercury; LOQ: limits of quantification; $\mathrm{N}$ < LOQ: number of values below LOQ; PB: lead; Ref.: reference; RSF: recycling sorting facilities; SD: standard deviation.

* Non-smokers.

In the univariate analysis, "the RSF where the collectors work", "payment of social security", "previous work on another RSF", "previous work on a different occupation", "smoking habit", "hair treatment" and "COPD risk" were associated with blood Cd levels $(\mathrm{p}<0.05)$.

The generalized linear model retained only "the RSF where the collectors work" (higher concentrations on RSF C), "working in another occupation" (protective factor), and "smoking habit" as factors with statistical significance associated with blood Cd levels (Table 3).

Regarding $\mathrm{Pb}$, factors associated with higher levels $(\mathrm{p}<0.05)$ in the univariate analysis included "the RSF where the collectors work", "sex", "age", "work in the storage sector"; "work in the administrative sector", "previous work on another RSF", "consumption of distilled beverages", "beer consumption", "meat consumption", "smoking habit", "hair treatment" and "risk for developing COPD".

The generalized linear model retained "the RSF where the collectors work" (RSF B more relevant), "sex", "smoking", "age" and "meat consumption" as factors statistically significantly associated with blood Pb levels (Table 4).

In the univariate analysis, $\mathrm{Hg}$ was associated with "time of work in the current RSF", "working in feeding the screening conveyor belt", "previous work on another RSF", "fish consumption", "COPD risk" and "pneumonia in the last year" ( $\mathrm{p}<0.05)$. The associated factors retained in the generalized linear model were "previous work in other RSF", "fish consumption" and "time of work in the current RSF" (Table 5).

One individual had blood $\mathrm{Pb}$ of $207 \mu \mathrm{gL}-1$ and seven had $\mathrm{Hg}$ levels above the HBM I, thus these individuals were referred to the occupational health service for further investigation. No individual presented blood Cd levels above the limit considered for supplementary evaluation. 
Table 3

Factors associated with Cd (cadmium) concentration in the study group. São Paulo, Brazil, 2014.

\begin{tabular}{lccc}
\hline Characteristic & Coefficient & SE & p-value \\
\hline RSF & & & \\
A & 0.221 & 0.068 & 0.001 \\
B & 0.225 & 0.053 & $<0.001$ \\
C & 0.330 & 0.061 & $<0.001$ \\
D & Ref. & & \\
Work in another occupation & & & \\
Yes & -0.182 & 0.061 & \\
No & Ref. & & 0.003 \\
Smoking habit & & & \\
Former smoker & 0.104 & 0.056 & $<0.001$ \\
Smoker & 0.479 & 0.063 & - \\
Non-smoker & Ref. & - & \\
\hline
\end{tabular}

Ref.: reference; RSF: recycling sorting facilities; SE: standard error.

Table 4

Factors associated with Pb (lead) concentration in the study group. São Paulo, Brazil, 2014.

\begin{tabular}{lccc}
\hline Characteristic & Coefficient & SE & p-value \\
\hline RSF & & & \\
A & -1.03 & 2.92 & 0.723 \\
B & 17.20 & 3.44 & $<.001$ \\
C & -3.00 & 2.26 & 0.185 \\
D & Ref. & & 0.002 \\
Sex (male) & 7.87 & 2.56 & \\
Smoking habit & & & 0.006 \\
Smoker & 6.43 & 2.34 & 0.616 \\
Former smoker & 1.27 & 2.53 & $<0.001$ \\
Non-smoker & Ref. & & 0.003 \\
Age (years) & 0.41 & 0.09 & 0.63 \\
Meat consumption & -1.85 & & \\
\hline
\end{tabular}

Ref.: reference; RSF: recycling sorting facilities; SE: standard error.

Table 5

Associated factors with $\mathrm{Hg}$ (mercury) concentration on the study group. São Paulo, Brazil, 2014.

\begin{tabular}{lccc}
\hline Characteristic & Coefficient & SE & p-value \\
\hline Work on another RSF & 0.63 & 0.19 & 0.001 \\
Fish consumption & & & 0.022 \\
$\quad$ Frequent & 1.53 & 0.67 & 0.014 \\
$\quad$ Rare & 0.38 & 0.15 & - \\
$\quad$ Never & Ref. & - & 0.002 \\
Length of time working in the current RSF (days) & 0.0002 & 0.00007 & \\
\hline
\end{tabular}

Ref.: reference; RSF: recycling sorting facilities; SE: standard error. 


\section{Discussion}

To our knowledge, this is the first study to evaluate the blood metal content of recycling material collectors, a profession that enrolls several thousand workers in Brazil and in other countries in Latin America. We found out that collectors working at RSF in the Metropolitan Region of São Paulo have blood $\mathrm{Cd}$ levels four times higher and blood $\mathrm{Pb}$ levels 1.4 times higher than the general non-occupationally exposed population of the region. Mean blood levels of $\mathrm{Hg}$ among this population were not statistically different from the reference population 24 .

The mean blood content of $\mathrm{Cd}$ among these workers was also high compared to another Brazilian study conducted in São Paulo (AM: 0.24 $\mathrm{gL}^{-1}$ ), although the methodology and population characteristics were not exactly comparable 25. Another study conducted in 5 different Brazilian states found similar mean levels for Cd (GM: $\left.0.4 \mu \mathrm{gL}^{-1}\right)$, but they included active smokers in their sample and the analytical method was not the same as employed in our study 26 .

Our results were also higher than that found in populations in the United States 27 (AM: $0.3 \mu \mathrm{gL}^{-1}$, including smokers), Czech Republic 28 (GM: $0.3 \mu g L^{-1}$; not including smokers) and Finland 29 (GM: $0.18 \mu \mathrm{gL}^{-1}$ for males and $0.12 \mu \mathrm{gL}^{-1}$ for females, not including smokers). On the other hand, the values found on the present study were lower than the reference values for Cd in Germany 30 (reference value: $1.0 \mu \mathrm{gL}-1)$. However, it should be noted that mean Cd blood level in the German population are higher than other countries, including Brazil 23,24. We did not find studies that evaluated Cd blood levels in workers of formal or informal recycling sites.

The levels of $\mathrm{Cd}$ found in the present study indicates a higher concentration of this metal on the collectors compared to non-occupationally exposed population.

As expected, "smoking" was associated to higher Cd content in our study, as cigarette is a known source of Cd 14. On the other hand, "previous work on another occupation" was inversely associated with Cd blood levels, which reinforces the hypothesis that the recycling activities developed at the RSF can be associated to specific exposure due to the process of handling materials that contain Cd.

We observed that workers at RSF C presented the highest Cd levels, but we could not identify any specific population characteristic or any different process developed at this RSF that could explain this result. This finding stresses the need for further investigations of the working process developed during activities that might cause higher exposure to this metal among recycling workers.

In general, the process in the RSF mainly involves the handling of large amounts of plastic and paper, a process that occurs at the separation mats and the compaction area. Working specifically in these positions, however, was not associated with any different metal blood content among workers.

The use of personal protective equipment (glasses, boots and gloves), although reported in the questionnaire, was not frequently observed during data collection. In addition, due to the amount of accumulated waste, hygiene conditions can contribute to the exposure to metals by aspiration of contaminated particulate matter and by oral contamination (hand-to-mouth process), although we could not evaluate this hypothesis with the collected data.

Mean blood content of $\mathrm{Pb}$ among these workers was high compared to another study also conducted in São Paulo 25 (AM: 19.8 $\mu \mathrm{gL}^{-1}$ ), but again the analytical methodology and population characteristics of this study were not the same as ours. Our results were similar to what has been found in a study conducted in the Brazilian Western Amazon, but that study included individuals with a previous history of exposure in activities related to paints, ceramics, pottery, fishing, or firearms (GM: $40.78 \mu \mathrm{gL}^{-1}$ from men, $27.40 \mu \mathrm{gL}^{-1}$ for women) 31 . On the other hand, the mean concentration of $\mathrm{Pb}$ on our study was lower than the results found in the study conducted by Nunes 26 (GM: $65.4 \mu \mathrm{gL}-1$ ).

The results found in the present study were also higher than the ones found in United States 27 (GM: $12.3 \mu \mathrm{gL}^{-1}$ ), Czech Republic 28 (AM: $23 \mu \mathrm{gL}^{-1}$ for males and $14 \mu \mathrm{gL}^{-1}$ for females), Finland 29 (GM: $17.0 \mu \mathrm{gL}^{-1}$ for males and $9.06 \mu \mathrm{gL}^{-1}$ for females) and German 30 (AM: $22 \mu \mathrm{gL}^{-1}$ ).

In Ghana, a study on informal-level electronic waste (e-waste)-processing activities found that the workers had mean blood $\mathrm{Pb}$ level of $88.5 \mu \mathrm{gL}^{-1}$, higher than the results found in the present study. It is worth noting that the process applied to e-waste recycling in Ghana and other countries such as China and India includes burning, which requires close contact with fumes originating from the direct combustion of electronic waste products 12 . 
When compared to $\mathrm{Pb}$ levels found in a formal recycling plant in Sweden $(32 \mu \mathrm{gL}-1)$, our study found higher blood $\mathrm{Pb}$ levels 11 .

Therefore, our results indicate a higher $\mathrm{Pb}$ concentration among collectors compared to the general population and workers from a formal recycling plant, but lower $\mathrm{Pb}$ levels than recycling workers of informal sites and populations with high risk of exposure to this metal.

Regarding the associated factors, "age" and "gender" are known factors associated with higher blood $\mathrm{Pb}$ levels 13,32.

"Smoking" was also associated with higher $\mathrm{Pb}$ content in our study and cigarettes are a known source of $\mathrm{Pb}{ }^{13}$. It must be noted, however, that even when we examined only non-smoking collectors, their mean blood $\mathrm{Pb}$ levels were still significantly higher than the non-occupationally exposed population of São Paulo (data not shown).

We found that "meat consumption" was a factor associated with lower Pb levels. We could not identify any association between meat consumption and blood $\mathrm{Pb}$ levels in the literature and our hypothesis is that this variable might just be acting as a proxy for better socioeconomic condition, a factor that has been shown in some studies to be associated with lower blood $\mathrm{Pb}$ levels 33,34.

The higher concentrations of $\mathrm{Pb}$ on the RSF B could be reflecting the lower socioeconomic characteristics of the population in this RSF. Although collectors of recycling material were considered a homogenous group regarding socioeconomic characteristics, differences were found among them. RSF B recruited collectors that are homeless or individuals just released from prison, while others have a more stable population of workers, slightly better off economically. The differences in socioeconomic status and on specific sources of $\mathrm{Pb}$ exposure could explain these findings, however we could not evaluate this hypothesis with the data we collected.

The mean blood $\mathrm{Hg}$ concentration was not significantly different from the reference study and was not higher than the results found in Sweden $(1.4 \mu \mathrm{gL}-1)$ in a formal recycling plant 11.

Analyses of air samples to evaluate the exposure to $\mathrm{Hg}$ in the same 4 RSF we studied showed concentrations well below the occupational reference values, point out that the workers are not exposed to $\mathrm{Hg} 35$.

Although the mean concentration of $\mathrm{Hg}$ among all collectors was not different from the reference study, the mean level in RSF B was significantly higher. All seven individuals with Hg levels above the HBM I ( $\left.5 \mu \mathrm{gL}^{-1}\right)$ belonged to that RSF and could have been exposed to the same source. We did not collect data that allow us to explore this possibility which deserves further investigation.

The factors associated with blood $\mathrm{Hg}$ concentrations were "fish consumption", "have worked in another RSF", and "length of time working in the current RSF". Higher blood Hg levels are usually associated with fish consumption 15. "Work in another RSF" and "length of time working in the current RSF" can be related to the duration of exposure to Hg sources, although we could not evaluate this hypothesis with the data we collected.

We observed no association between e-waste recycled and the blood metal content of the collectors. Even though the facilities did not report the exact amount of electronic equipment received monthly, this kind of material was found in all sites visited. In addition, during fieldwork we notice the presence of fluorescent lamps in some of the RSF which could be an important source of $\mathrm{Hg}$ exposure 6 .

During the interviews with the president or secretary of the RSF, they reported not usually receiving this type of material, but when this occasionally occurs, the collectors would be instructed to not handle the lamps and send them directly to special recycling sites. This might explain the finding of a general mean concentration of $\mathrm{Hg}$ not significantly different than the reference population.

This study has some important limitations that warrant mention. First, the number of collectors included was lower than what was estimated as the necessary sample size and therefore we lacked statistical power. Nevertheless, we were able to identify higher blood metal content among these workers and factors associated with these levels. In addition, we considered collectors a priori as a homogeneous low socioeconomic group. Thus, apart from questions regarding school attendance, socioeconomic data was not included in the questionnaire. Additionally, during the interviews we noticed some difficulty among the collectors in informing their food consumption habits and previous work experience. All of this information bias might have played a role in our results. 
One important aspect that cannot be disregard is the fact that the population of workers from our study is constituted by highly vulnerable individuals of low socioeconomic status, a known risk factor for higher $\mathrm{Cd}$ and $\mathrm{Pb}$ levels 13,14,33, and this may, in part, explain their higher mean metal levels compared to other population groups.

Our main objective was to verify the health risks involved in the work carried out in RSF of recycling materials in Brazil. While there is a large body of evidence suggesting occupational health risks associated specifically with e-waste recycling, such evidence is lacking in our context where recycling of e-waste does not play a major role, but other important sources of chemical contamination might exist. Although according to Brazilian policies for solid waste 4 and the Brazilian Program of Occupational Health the RSF must have minimum occupational safety standards 36 , the working conditions observed in most RSF can be characterized as unsafe, with poor use of personal protective equipment (PPE), and with unknown hazards that deserves further evaluation.

\section{Conclusion}

The activity of recycling material collectors is the main source of income for around 600,000 families in Brazil and has been recognized as an important part of the solid waste management process. This activity is also present in several countries, and it is of utmost importance to evaluate the health risks involved in it, in an attempt to promote better quality of life for this group of people.

This study indicates that recycling material collectors have higher levels of $\mathrm{Cd}$ and $\mathrm{Pb}$ compared to the general population and thus further studies should be performed to evaluate the relation of metal exposure and the process developed at the RSF.

\section{Contributors}

M. M. Ferron, R. Kuno and N. Gouveia participated in the conception and design, draft and review of the article, final approval of the version to be published and agreement to be accountable for all aspects of the work. A. E. M. Campos contributed in acquisition and interpretation of data, draft and review of the article, final approval of the version to be published and agreement to be accountable for all aspects of the work. F. J. V. Castro collabored in the analysis and interpretation of data, draft and review of the article, final approval of the version to be published and agreement to be accountable for all aspects of the work.

\section{Additional informations}

ORCID: Mariana Maleronka Ferron (0000-00015041-3231); Rúbia Kuno (0000-0003-1459-5802); Anali Espindola Machado de Campos (0000-00015537-2598); Francisco José Viana de Castro (00000002-5133-4081); Nelson Gouveia (0000-00030625-0265).

\section{Acknowledgments}

We would like to thank Brazilian National Movement of Recycling Collectors (MNCR) for their support throughout the entire process of preparing this study. 


\section{References}

1. Dagnino RS, Johansen IC. Os catadores no brasil: características demográficas e socioeconômicas dos coletores de material reciclável, classificadores de resíduos e varredores a partir do Censo Demográfico de 2010. Boletim Mercado de Trabalho - Conjuntura e Análise 2017; (62):115-25.

2. Espinoza PT, Arce EM, Daza D, Faure MS, Terraza H. Report on the regional evaluation of municipal solid waste management services for Latin America and the Caribbean. Washington DC: Pan American Health Organization; 2005.

3. Bosi AP. A organização capitalista do trabalho "informal": o caso dos catadores de recicláveis. Rev Bras Ciênc Soc 2008; 23:102-16.

4. Associação Brasileira de Empresas de Limpeza Pública e Resíduos Especiais. Panorama dos resíduos sólidos no Brasil, 2017. São Paulo: Associação Brasileira de Empresas de Limpeza Pública e Resíduos Especiais; 2017.

5. Brasil. Lei no 12.305, de 02 de agosto de 2010. Institui a Política Nacional de Resíduos Sólidos, cria o Comitê Interministerial da Política Nacional de Resíduos Sólidos e o Comitê Orientador para a Implantação dos Sistemas de Logística Reversa, e dá outras providências. Diário Oficial da União 2010; 3 aug.

6. Moreira AMM. Riscos e agravos à saúde do trabalhador em centrais de triagem de materiais recicláveis [Doctoral Dissertation]. São Paulo: Faculdade de Saúde Pública, Universidade de São Paulo; 2017.

7. Oliveira DAM. Percepção de riscos ocupacionais em catadores de materiais recicláveis: estudo em uma cooperativa em Salvador-Bahia [Master's Thesis]. Salvador: Faculdade de Medicina da Bahia, Universidade Federal da Bahia; 2011.

8. Ferron MM, Lima AK, Saldiva PHN, Gouveia N. Environmental lead poisoning among children in Porto Alegre state, Southern Brazil. Rev Saúde Pública 2012; 46:226-33.

9. Swedish Environmental Protection Agency. Recycling and disposal of electronic waste. Bromma: Swedish Environmental Protection Agency; 2011. (Report, 6417).

10. Capelini M. Potencialidade e aplicação da prevenção de resíduos de embalagens: abordagem sobre o projeto do produto e o consumo [Doctoral Dissertation]. São Carlos: Escola de Engenharia de São Carlos, Universidade de São Paulo; 2007.

11. Julander A, Lundgrenab L, Skarea L, Grandão M, Palma B, Vahtera M, et al. Formal recycling of e-waste leads to increased exposure to toxic metals: an occupational exposure study from Sweden. Environ Int 2014; 73:243-5.

12. Wittsiepe J, Feldt T, Till H, Burchard G, Wilhelm M, Fobil JN. Pilot study on the internal exposure to heavy metals of informal-level electronic waste workers in Agbogbloshie, Accra, Ghana. Environ Sci Pollut Res Int 2017; 24:3097-107.
13. Agency for Toxic Substances and Disease Registry. Toxicological profile for lead. Atlanta: Agency for Toxic Substances and Disease Registry; 2019.

14. Agency for Toxic Substances and Disease Registry. Toxicological profile for cadmium. Atlanta: Agency for Toxic Substances and Disease Registry; 2012.

15. Agency for Toxic Substances and Disease Registry. Toxicological profile for mercury. Atlanta: Agency for Toxic Substances and Disease Registry; 1999.

16. Kuno R. Valores de referência para chumbo, cádmio e mercúrio em população adulta da Região Metropolitana de São Paulo [Doctoral Dissertation]. São Paulo: Faculdade de Medicina, Universidade de São Paulo; 2009.

17. Buschinelli JT. Manual de orientação sobre controle médico ocupacional da exposição a substâncias químicas. São Paulo: Fundação Jorge Duprat Figueiredo de Segurança e Medicina do Trabalho; 2014.

18. Kummrow F, Silva FF, Kuno R, Souza AL, Oliveira PV. Biomonitoring method for the simultaneous determination of cadmium and lead in whole blood by electrothermal atomic absorption spectrometry for assessment of environmental exposure. Talanta 2008; 75:24652.

19. United States Environmental Prtotection Agency. Method 7473 (SW-846): mercury in solids and solutions by thermal decomposition, amalgamation and atomic absorption spectrophotometry. Revision 0. Washington DC: United States Environmental Prtotection Agency; 2007.

20. Bagatin E, Jardim JRB, Stirbulov R. Doença pulmonar obstrutiva crônica ocupacional. J Bras Pneumol 2006; 32 Suppl 1:S35-40.

21. Landrigan P, Nordberg M, Lucchini R, Nordberg G, Grandjean P, Iregren A, et al. The Declaration of Brescia on prevention of the neurotoxicity of metals June 18, 2006. Am J Ind Med 2007; 50:709-11.

22. American Conference of Governmental Industrial Hygienists. TLVs and BEIs baseados na documentação dos limites de exposição ocupacional (TLVs) para substâncias químicas e agentes físicos \& índices biológicos de exposição (BEIs). São Paulo: Associação Brasileira de Higienistas Ocupacionais; 2014.

23. Schulz C, Wilhelm M, Heudorf U, KolossaGehring M. Update of the reference and HBM values derived by the German Human Biomonitoring Commission. Int J Hyg Environ Health 2011; 215:26-35.

24. Kuno R, Roquetti MH, Becker K, Seiwert M, Gouveia N. Reference values for lead, cadmium and mercury in the blood of adults from the metropolitan area of São Paulo, Brazil. Int J Hyg Environ Health 2013; 216:243-9. 
25. Kira CS, Sakuma AM, Capitani EM, Freitas CU, Cardoso MRA, Gouveia N. Associated factors for higher lead and cadmium blood levels, and reference values derived from general population of São Paulo, Brazil. Sci Total Environ 2016; 543(Pt A):628-35.

26. Nunes JA, Batista BL, Rodrigues JL, Caldas NM, Gomes Neto JA, Barbosa Jr. F. A simple method based on icp-ms for estimation of background levels of arsenic, cadmium, copper, manganese, nickel, lead, and selenium in blood of the Brazilian population. J Toxicol Environ Health A 2010; 73:878-87.

27. Centers for Disease Control and Prevention. Fourth national report on human exposure to environmental chemicals. Atlanta: Centers for Disease Control and Prevention; 2009.

28. Cerná M, Krsková A, Cejchanová M, Spevácková V. Human biomonitoring in the Czech Republic:an overview. Int J Hyg Environ Health 2012; 215:109-19.

29. Abass K, Koiranen M, Mazej D, Tratnik JS, Horvat M, Hakkola J, et al. Arsenic, cadmium, lead and mercury levels in blood of Finnish adults and their relation to diet, lifestyle habits and sociodemographic variables. Environ Sci Pollut Res 2016; 24:1347-62.

30. Heitland P, Koster HD. Biomonitoring of 37 trace elements in blood samples from inhabitants of northern Germany by ICP-MS. J Trace Elem Med Biol 2006; 20:253-62.
31. Freire C, Koifman RJ, Fujimoto D, Souza VCO, Barbosa Jr. F, Koifman S. Reference values of lead in blood and related factors among blood donors in the Western Amazon, Brazil. J Toxicol Environ Health 2014; 77:426-40.

32. United Nations Environment Programme. Final review of scientific information on lead. https://www.cms.int/sites/default/files/ document/UNEP_GC26_INF_11_Add_1_Final_UNEP_Lead_review_and_apppendix_ Dec_2010.pdf (accessed on 31/Oct/2019).

33. Belova A, Greco SA, Riederer AM, Olsho LEW, Corrales MA. A method to screen U.S. environmental biomonitoring data for race/ethnicity and income-related disparity. Environ Health 2013; 12:114.

34. Hrncirova D, Batariová A, Cerná M, Prochazka B, Dlouhy P. Exposure of Prague's homeless population to lead and cadmium, compared to Prague's general population. Int J Hyg Environ Health 2008; 211:580-6.

35. Gouveia N, Buzzo ML, Grossi MGL, Muto EY. Exposição ocupacional ao mercúrio em cooperativas de triagem de materiais recicláveis da região metropolitana de São Paulo, SP, Brasil. Ciênc Saúde Colet 2019; 24:1517-26.

36. Secretaria de Segurança e Saúde no Trabalho, Ministério do Trabalho. Portaria no 24, de 29 de dezembro de 1994. Diário Oficial da União 1994; 30 dec. 


\section{Resumo}

Cerca de 600 mil brasileiros trabalham na coleta e separação de materiais recicláveis, mas há poucos estudos que avaliam os riscos de saúde envolvidos nessa ocupação. O estudo teve como objetivos avaliar os níveis sanguíneos de cádmio $(C d)$, chumbo $\mathrm{Pb}$ ) e mercúrio $(\mathrm{Hg})$ em trabalhadores de centros de reciclagem na Região Metropolitana de São Paulo, Brasil, além de comparar os resultados com uma população sem exposição ocupacional e identificar fatores associados com níveis elevados desses metais pesados no sangue. Foram selecionados quatro centros de reciclagem, e 226 trabalhadores foram testados para os níveis sanguíneos dos metais e fatores associados. As concentrações médias

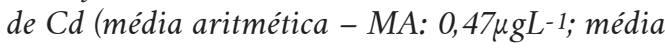
geométrica - MG: 0,34 $\mu \mathrm{gL}-1$ ) eram quase quatro vezes mais altas que aquelas encontradas em um estudo de referência. De acordo como o modelo linear generalizado (MLG), os fatores "centro de reciclagem onde o individuo trabalha", "trabalho em outra ocupação" e "tabagismo" apareceram como preditores estatisticamente significativos de níveis mais altos de $C d$. As concentrações médias

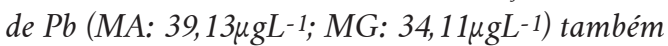
eram mais altas (cerca de 1,4 vezes) que no estudo de referência e os fatores associados no MLG eram "centro de reciclagem onde o indivíduo trabalha", "sexo", "tabagismo", "idade" e "consumo de carne".

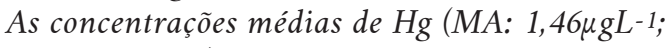
$M G: 0,94 \mu g L^{-1)}$ não eram significativamente mais altas que na população de referência, e os fatores associados eram "trabalho prévio em outro centro de reciclagem", "consumo de peixe" e "anos de trabalho no centro de reciclagem atual". O estudo indica que os trabalhadores de reciclagem apresentam níveis sanguíneos mais elevados de $\mathrm{Cd} e \mathrm{~Pb}$, comparado com os níveis na população geral.

Exposição Ocupacional; Chumbo; Cádmio; Mercúrio

\section{Resumen}

Alrededor de 600.000 personas trabajan como recolectores de materiales para reciclar en Brasil, además de existir pocos estudios que evalúen los riesgos de salud implicados en esta ocupación. El objetivo fue evaluar los niveles de cadmio en sangre $(\mathrm{Cd})$, plomo $(\mathrm{Pb})$ y mercurio $(\mathrm{Hg})$ entre los trabajadores de plantas de reciclaje (RSF por sus siglas en inglés), en la región metropolitana de São Paulo, Brasil, comparando los resultados con la población no expuesta ocupacionalmente, e identificando los factores asociados con niveles más altos de metal en la sangre. Se seleccionaron 4 plantas de reciclaje y se examinaron a 226 recolectores para analizar los niveles de metales en sangre $y$ sus factores asociados. La concentración media de Cd (media aritmética - MA: 0,47 $\mu \mathrm{gL}^{-1}$; media geométrica - MG: 0,34 $\left.\mu \mathrm{gL}^{-1}\right)$ fue casi cuatro veces mayor que la que se encontró en el estudio de referencia. El modelo lineal generalizado (GLM) indicó que las "las RSF donde trabajan los recolectores", "trabajo en otra ocupación", y "fumador" fueron predictores significativos estadisticamente de los niveles de Cd en sangre. La concentración

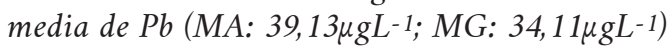
también fue mayor que la observada en el estudio de referencia (sobre 1, 4 veces) y los factores asociados en el GLM fueron: "las RSF donde trabajan los recolectores", "sexo", "fumador", "edad" y "consumo de carne". La concentración media de $\mathrm{Hg}$ (MA:

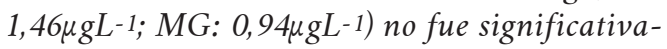
mente mayor que en la población de referencia $y$ los factores asociados fueron "trabajo previo en otra RSF", "consumo de pescado" y "años de trabajo en la actual RSF”. Este estudio indica que los recolectores de material reciclable tienen niveles más altos en sangre de Cd y $\mathrm{Pb}$, si se comparan con la población general.

Exposición Profesional; Plomo; Cadmio; Mercurio

Submitted on 12/Apr/2019

Final version resubmitted on 16/Jan/2020

Approved on 27/Jan/2020 